\title{
Terminal Care and Death Through the Eyes of Turkish Nursing Students: A Qualitative Research Study
}

\section{Türk Hemşirelik Öğrencilerinin Gözünden Yaşam Sonu Bakım ve Ölüm: Bir Kalitatif Araştırma}

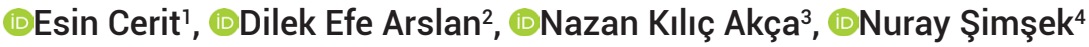 \\ 'Yozgat Bozok University, Faculty of Health Sciences \\ ${ }^{2}$ Erciyes University, Halil Bayraktar Vocational School of Health Services \\ 3izmir Bakırçay University, Faculty of Health Science \\ ${ }^{4}$ Erciyes University, Faculty of Health Sciences \\ Copyright@Author(s) - Available online at www.dergipark.org.tr/tr/pub/medr \\ Content of this journal is licensed under a Creative Commons Attribution-NonCommercial 4.0 International License.
}

\begin{abstract}
Aim: This study was aimed to determine the thoughts and feelings of nursing students emerging during the provision of care to terminally ill patients.

Material and Method: It is a qualitative study. The study population consisted of 12 students who volunteered to participate in the study. Data were collected using a semi-structured interview form and focus group interview technique. Descriptive and content analysis techniques were used for the data analyses.

Results: The study found out that the majority of the students defined death as a "sad ending" and "loss". Some students stated that they kept an attitude of acceptance, while others stated that they experienced intense feelings of fear when they encountered death. The students stated that they generally felt sorry for the patient, felt ineffective, and experienced an intensification of their fears of death when providing care for terminally ill patients. Furthermore, all of the students said that terminal care should aim to "minimize pain and provide an abundance of resources".

Conclusion: This study shows that nursing students need to get more education about terminal care and that further qualitative studies should be conducted to investigate the feelings of nursing students from various aspects.
\end{abstract}

Keywords: Nurse, student, terminal period, death

Öz

Amaç: Araştırma, terminal dönem hastalarına bakım veren hemşirelik öğrencilerinin bakım sırasında yaşadıkları duygular ve ölüm hakkındaki düşüncelerini belirlemek amacıyla planlanmıştır.

Materyal ve Metot: Araştırma nitel desende tasarlanmıştır. Araştırma grubunu, çalışmaya katılmaya gönüllü olan 12 öğrenci oluşturmaktadır. Veriler yarı yapılandırılmış görüşme formu ve odak grup görüşmesi tekniği ile toplanmıştır. Verilerin analizinde, betimsel analiz ve içerik analizi tekniği kullanılmıştır.

Bulgular. Araştırmada, öğrencilerin büyük çoğunluğu ölümü "Hüzün verici bir son ve kayıp" olarak tanımlamıştır. İlk defa ölümle karşılaştıklarında bazı öğrenciler kabullenici bir tutum sergilediğini, bazıları ise korku duygusunu yoğun olarak yaşadıklarını ifade etmişlerdir. Öğrenciler, terminal dönem hastalarına bakım verirken genellikle hasta için üzüldüklerini, çersizlik hissettiklerini ve kendi adlarına da ölüm korkularının arttığını belirtmişlerdir. Ayrıca öğrencilerin tamamı, terminal dönem bakımın amacının, "az ağrı ve refah içinde ölüm" şeklinde olması gerektiğini söylemiştir.

Sonuç: Bu araştırma, hemşirelik öğrencilerinin terminal dönem bakımı konusunda daha fazla eğitime ihtiyaçları olduğunu ve bu konuda öğrencilerin duygularının farklı boyutlarıyla da ele alındığı nitel çalışmaların artırılması gerektiğini göstermektedir.

Anahtar Kelimeler : Hemşire, öğrenci, terminal dönem, ölüm 


\section{INTRODUCTION}

"Death" is a universal phenomenon that happens unexpectedly regardless of the social position or the situation the person is in. Death is a concept difficult to define. In the face of death, humans attribute many meanings to death and react accordingly (1). When the reaction to death is excessive, immoderate or pathological; anxiety levels of people increase and adjustment to the environment is disturbed (2). When the response to death is an attitude of acceptance, the person can live a life to apply his or her values, alleviating the death anxiety.

Due to the technological advances and parallel medical innovations, death is considered a disease or a condition to be struggled against rather than being perceived as a natural process. For this reason, death can be considered as an event within a hospital. Nurses spend most of their time with patients in hospitals, therefore, they are constantly posed to face death. This is why nurses define terminal care and the process of death as one of the most challenging aspects of their profession (3). Several conditions complicate the death process, including the progressive deterioration of the patient's condition, difficulties in treating the symptoms, and the helplessness feelings of the patient's relatives $(4,5)$. Death is a challenging process and terminal care mainly aims to ensure the physical and psychological comfort of the patient to increase the quality of life (6). In order to raise awareness in nurses responsible for the provision of care, they should be trained and supervised on the physical, emotional, intellectual, social, and spiritual dimensions of end-of-life care throughout their education (2). Furthermore, students should be trained primarily to identify and control their emotions $(7,8)$. Özer et al.'s study (2015) on student nurses found that assuming the care provider role for a terminally ill patient caused anxiety and that the reason of the anxiety was not related to the fear of death of the student nurses but occurred due to their feelings of inadequacy and helplessness in informing and directing the patient (9). In studies conducted abroad (911) students reported that their feelings of helplessness were caused by getting insufficient training about how to prepare the patient to death. Despair negatively affects students' provision of care to patients in the process of death. In a study performed by Şahin et al. (2016), $62.2 \%$ of nursing students stated that they would not like to provide care to a terminally ill patient (4). In a study by Youssef (2016), it was reported that $83.3 \%$ of nursing students developed negative feelings and thoughts towards terminal care patients and their families (12).

First of all, the students' feelings and thoughts about death should be identified in all aspects so that the students can effectively communicate with terminal care patients; manage their emotions, help themselves relieve feelings of helplessness, provide a standard care appropriately, and ensure that patients die in dignity. This study is expected to contribute to the literature by identifying student nurses' feelings and thoughts about death based on the results obtained from in-depth interviews. The aim of this study is to identify the feelings and thoughts of student nurses about the provision of care to terminally ill patients in Turkey.

\section{MATERIAL AND METHOD}

\section{Type of Research}

This study has aimed to comprehensively investigate the student nurses' feelings and thoughts about death during care provision to terminally ill patients and to compile a holistic view of the participants, it has been designed as a focus group study, which is one of the qualitative research methods.

Focus group interviews have been selected as a qualitative research method since they are one of the most appropriate methods to identify the feelings, thoughts, perceptions, and attitudes of individuals. Furthermore, focus group interviews provide in-depth information and allow brainstorming by using group dynamics (13). All senior student nurses, who volunteered to participate in the study, were included in the study without using any pre-specified method for participant selection.

\section{Population and Sample of the Research}

The study was carried out in a vocational healthcare high school in Central Anatolian Region in Turkey. Focus group interviews were conducted with the participating students in the meeting room at scheduled times. The interviews were carried out between 25.11.2018 and 29.11.2018.

Study Group: In compliance with the study design, the study group consisted of 12 fourth-grade nursing students, comprising 4 men and 8 women, volunteered to participate in the study. Male students were given the ' $M$ ' code (M1-4). Female students were given the ' $F$ ' code (F1-8). The students attended the 2017-2018 academic year at the time of the study and they provided care to terminally ill patients during their education. The students were coded to facilitate the documentation of the findings. The aliases of the students could be found on their ID badges during the interviews.

Inclusion criteria in the research: Inclusion criteria are being a 4th grade student, providing care to a terminalperiod patient during their education and volunteering to participate in the study.

Exclusion criteria in the research: Students of $1 \mathrm{st}, 2 \mathrm{nd}$ and 3 rd years and 4 th year students who did not provide terminal period patient care were not included in the study.

\section{Data Collection}

There was a U-shaped table in the meeting room, allowing the participants to see each other. Appropriate environmental conditions (noise, light, temperature, ventilation, etc.) was ensured in the meeting room so that the interviews were conducted comfortably and trustfully. Before starting the interviews, refreshments and equipments (drinking water, pencil, paper, etc.) were 
put on the table for the use of the participants. The comments of the students were recorded by a smartphone after obtaining their consent. Before the interviews, the meeting room was prepared by the investigator. Interviews were conducted in two sessions outside the class hours of the students. Each session took 30-40 minutes, considering the suitability of the students. All 12 students were present at the interviews.

The focus group interviews were moderated by an investigator. Additionally, another investigator was present during the interview to note the verbal and nonverbal statements of the students and the investigator, too. During the interviews, it was explained to the students that they could revisit the previous question and that they were allowed to express their ideas freely.

\section{Data Collection Instruments}

\section{Introductory Information Form}

The introductory information form consisted of three questions to document the age and gender of the students and the time when they encountered terminally ill patients.

\section{Interview Form}

A semi-structured interview form was used in the study to reveal the students' experiences in depth. The interview form was developed using the information obtained from the literature review (14-17) and by using the subdimensions (Neutral Acceptance, Escape Acceptance, Escape from Death and Fear) of the Attitude To Death Scale (15). There are four open-ended questions in the interview form. Interview questions were as follows:

1-What does death mean to you?

2-What did you feel at your first encounter with death?

3- How did you feel when providing care to the terminally ill patient?
4-In your opinion, what should be the main purpose of care provided during the terminal period?

\section{Data Analysis}

The characteristics of patients were analyzed using SPSS version 23.0 (IBM Corp., Armonk, NY, USA). Percentages, frequencies, means, median, standard deviations, and ranges were used to define sociodemographic sample characteristics. Content analyses were used for the qualitative data. Content analysis is one of the most commonly used methods in qualitative data analyses. Content analysis is primarily used for analyzing the written and visual data obtained from the focus group interviews. The data summarized and interpreted in the descriptive analysis is more deeply analyzed in the content analysis (18). The data obtained in the descriptive analysis were further analyzed by three investigators using content analysis so that any potentially unnoticed concepts and themes would be unfolded. The data analysis was carried out in the following four steps:

Step 1: The frequency and percentages were calculated using the quantitative data.

Step 2: By reading the interview reports of each participant repeatedly, the investigators identified the following themes, including the meaning of death, emergent feelings at the first encounter with death, the feelings experienced during the provision of care to the terminally ill patient, and the purpose of providing care to a patient in the terminal period.

Step 3: The identified themes were categorized according to the sub-dimensions of the Attitude To Death Scale (Neutral Acceptance, Escape Acceptance, and Fear and Avoidance of Death). Then, these themes were interpreted interactively, unfolding new concepts.

Step 4: At this final step, the themes and codes were summarized in a Table 1.

Table 1. Themes and Codes Associated With the Student's Feelings and Thoughts About Death During Provision of Care to Terminally III Patients

Themes

Codes

Theme 1. Meaning of Death

A sad ending and loss

Theme 2. Emergent Feelings at the First Encounter With Death

Theme 3. The Feelings Experienced During The Provision of Care to the Terminall III Patient
Neutral Acceptance, Escape Acceptance, and Fear and Avoidance of Death

Neutral Acceptance, Escape Acceptance, and Fear and Avoidance of Death

Theme 4. The Purpose of Providing Care to A Patient in the Terminal Period Neutral Acceptance, Escape Acceptance, and Fear and Avoidance has been identified. of Death 


\section{Ethical consideration}

To conduct the study, the permission of the institution and the approval of the Ethics Committee of the Bozok University were obtained (Approval date: 06.06.2018) Before commencing the interviews, the volunteering students were informed about the study and an "Informed Consent Form For Volunteers" was signed by the students who agreed to participate in the study.

Limitations of Research: This study had certain limitations. First, the limitations of the study are that it was conducted with a small group of students and it was conducted after a few years following the students' experiences. The latter made it difficult for the students to remember their memories and feelings at that time.

\section{RESULT}

The results are discussed in two sections. The first section addressed the quantitative findings including the descriptive characteristics of the students. The second section addressed the qualitative findings comprising the answers of the students to the interview questions.

\section{Sample Characteristics}

Table 2 presents the descriptive characteristics of the students. Of the participating students, $75 \%$ were women and they first encountered a terminally ill patient after they became a student nurse. The mean(median) age of the students was $20.41 \pm 1.16(20)$.

\section{Table 2. Sample Characteristics $(\mathrm{N}=12)$}

Sample Characteristics

Gender

Female

Male

Mean Age (years) $(X \pm$ SD)(min-max) (median)

First Encounter with A Terminall III Patient

Before Undergraduate Education

After Undergraduate Education

Total (N)

Note. SD = standard deviation

\section{Qualitative Findings}

The findings in this section were examined after being categorized under the following themes; including the meaning of death, emergent feelings at the first encounter with death, the feelings experienced during the provision of care to the terminally ill patient, and the purpose of providing care to a patient in the terminal period.

\section{Theme 1: Meaning of Death}

When the students were asked what death meant to them, the majority described it as "A sad ending and loss ". The definitions of death by the students are as follows:

"A sad ending and loss" (M1, M2, M3, F2, F6, F8)

"Salvation" (M4)

"A new beginning" (F1, F3, F4)

"Transition to Eternity" (F5)

"Real life" (F7)

Theme 2: Emergent Feelings at the First Encounter With Death

When students were asked to describe the feelings they experienced when they first encountered death, some of them informed that they kept an accepting attitude and some reported that they experienced a feeling of intense fear. The responses of the students are presented below under three codes including neutral acceptance, escape acceptance, and fear and avoidance of death:

a) Neutral Acceptance (M2, M3, F1, F2, F4, F5, F7)

"I thought that; one day, I will experience death, too. I felt that death was not as far away as I thought" (F1)

"It occurred to me that there might be an end to the life lived" (M2)

\section{b) Escape Acceptance (F3)}

"When I first encountered death, I felt very sorry. However, I later realized that it was salvation from mundane sufferings." (F3)

\section{c) Fear and Avoidance of Death (M1, M4, F6, F8)}

"At my first encounter with death, I intended to address it as a normal situation until when that frightening feeling inflicted me. Thinking that I might not find the patient in my next call was the scariest thought" (M1).

"I was scared. I didn't feel sorry for person who died; rather, I felt sorry for the relatives because it was sad to survive after the death of a deceased person" (M4). 
Theme 3: The Feelings Experienced During The Provision of Care to the Terminall III Patient

When students were asked to describe the feelings they experienced while caring of the patient in the terminal period, some students accepted the situation and perceived death as a salvation from the disease. However, most of the students informed that they usually felt sorry for the patient and that experience aggravated their fear of death.

a) Neutral Acceptance (M4, F1, F4)

"I realized that I felt sorry for the patient, but it didn't scare me. Rather, I considered it as a condition that would happen to everyone eventually" (M4).

"I knew death was the end for everyone. When I thought that the patient could have been my mother or father, I felt sad. Then, I continued to provide appropriate care to the patient. It was a pleasant feeling to be helpful and make the patient comfortable" (F4).

\section{b) Escape Acceptance (M3, F3, F5)}

"I thought that medicine was insufficient to relieve the pain and sufferings of patients and I wondered why it could not cure the diseases. This made me think that every ephemeral being would die one day for a reason. I felt terribly sorry" (M3)

"My patient had cancer and was in terrible pain, having no expectations from life. I thought death could be the only salvation for that patient. I thought that someday I would be in this patient's position. If I were the patient, I'd like to die, too." (F3)

c) Fear of Death (M1, M2, F2, F6, F7, F8, F9)

"To see a patient dying; to whom I provided care, scared me terribly and gave me pain. I felt that I provided empty solace to my patient; however, I saw that the person in front of me had not given up life, yet. This made me think that one could never give up life." (M1)

"I felt very sorry at times and I was sometimes terribly desperate. I was tired of trying not to show these feelings." (F7)

“The patient's respiratory distress and vulnerability scared me so much. I was very upset seeing that he/she lived in this condition. However, I tried to ensure that the patient would not feel that way at all."(M2)

\section{Theme 4: Purpose of Patient Care in Terminal Period}

All of the students said that the purpose of the care in the terminal period should be to "minimize pain and provide an abundance of resources". The expressions of the participating students are as follows:

F3 "It is to ensure that the patient was made comfortable and his/her sufferings were relieved, even making the death process free of any suffering. Thereby, people, who suffered too much, at least would not suffer when they die."
M3 "To ensure that the patient's pain is diminished, he/ she would die in peace and comfort, and he/she was assisted to enjoy himself/herself with the loved ones."

F5 "Care in the terminal period should minimize the pain of the patient, allow the patient to spend the end-of-life period peacefully at home, and the basic needs of the patient should be met".

\section{DISCUSSION}

The responsibility to sustain life is attained to student nurses during their education. Accordingly, nursing students assume responsibility for patient survival. However, the unpreventable character of death causes nursing students to experience negative emotions such as anxiety (19). American Association of Colleges of Nursing Palliative Competencies and Recommendations (2016) emphasizes that nursing students should be given training on end-of-life care (20). This way, student nurses can have the opportunity to elaborate attitudes towards their death and cope with end-of-life care problems.

Knowing the meaning of death for student nurses helps understand students' perspectives against death, determining the communication level of the patient. In our study, most of the students described death as a sad ending and loss. In the study conducted by Selçuk ve $\mathrm{Avcl}$ (2015) on university students, $82.3 \%$ of the students defined death as the beginning of a new life [21]. Bilge, Embel, and Kaya (2013) report that students, who will be future healthcare professionals, believe that death is a real and impending issue to be accepted and that death is a transition to another life after death (22). Our study results are different from those of the previously published studies in the literature. We can argue that this difference occurred because the participating students' perspectives about death were affected by the perspectives of the Central Anatolian population in Turkey.

Our study found out that the students experienced a neutral acceptance at their first encounter with death. A literature review of the studies from our country and abroad reveals that neutral acceptance is a widely used approach as shown by the Kumar et al. (2014) study and Bilge et al. (2013) study, investigating the students' attitudes towards death $(22,23)$. The similarity of our research findings to the literature indicates that nurses providing care for terminally ill patients encounter death frequently, perceiving death as a natural event that should be experienced and accepted.

In our study, the fear of death was the most common feeling experienced by the students during the provision of care for the terminally ill patient. Yılmaz and Vermişli (2015) found that, in young intensive care nurses, death anxiety was higher and their attitudes towards death were more negative compared to experienced nurses (24). A study on student nurses reported that during the provision of endof-life care, $17.2 \%$ of students experienced 'sadness' and $10.2 \%$ 'could not recognize their feelings (25). In a study by Özer et.al (2015) on student nurses, it was determined 
that the end-of-life care generated anxiety and angry (9). This anxiety may be the reflection of insufficiency and helplessness feelings of student nurses due to not knowing how to direct the patient and what to say. This finding might reflect insufficient professional experiences of student nurses and insufficient training provided to them during the undergraduate education, aiming to train them about how to approach death and how to cope with death-associated feelings.

Every individual has the right to receive effective care and treatment until the very last moment of his or her life. The nursing profession requires providing effective care to patients and helping to relieve their pain until the end of their lives $(8,26,27)$. During the provision of care to terminally ill patients, the responsibilities of nurses include relieving the sufferings of terminally ill patients and their families, providing adequate medical care, avoiding the use of methods with no additional benefits, making the patient comfortable, and providing adequate emotional and spiritual support. In the study by Gurkan, Gumus, and Dodak (2011), 79.6\% of student nurses stated that painful interventions applied to patients should be discontinued. In line with the information in the literature and the study findings of Gurkan, Gumus, and Dodak (2011), all of the participating student nurses in our study stated that the aim of terminal care should be to "minimize the suffering of the patient and provide an abundance of resources"(28).

\section{CONCLUSION}

The results of this study indicate that death affects all aspects of life, including physical, social, and psychological areas. We revealed that death and palliative care has common negative effects on students, regardless of cultural diversity. This finding might reflect insufficient professional experiences of turkish student nurses and insufficient training provided to them during the undergraduate education, aiming to train them about how to approach death and how to cope with deathassociated feelings.

Financial disclosures: All authors declare no financial support.

Conflict of Interest: TThe authors declared no potential conflicts of interestwithrespect to theresearch, authorship, and/or publication of this article.

Ethical approval: The approval of the Ethics Committee of the Bozok University were obtained (Approval date: 06.06.2018).

\section{REFERENCES}

1. Kübler-Ross E. On death and dying (Büyükal B, Translation Editor). Istanbul: Boyner Holding Publications; (Original study publication date 1969). 1997.

2. Öz F. Basic concepts in healthcare. Publisher: MATTEK, Ankara, 2010.

3. Parola V, Coelho A, Sandgren A, et al. Caring in palliative care: A phenomenological study of nurses' lived experiences.
JHPN. 2018;20:180-6.

4. Sahin M, Demirkiran F, Adana, F. Nursing students' death anxiety, Influencing factors and request of caring for dying people. J Psychiatric Nurs. 2016;7:135-41.

5. Uysal N, Ceylan E, Koc A. Nursing students' attitudes on care of dying Individuals. Gumushane University J Health Science. 2019;8:98- 05.

6. Patient Care In Terminal Period. Editor: Akdemir Nuran, Internal Diseases and Nursing Care. 6st edition. Publisher: Akademisyen Publication, Istanbul, 2019

7. Adesina O, DeBellis A, Zanettino L. Third-year Australian nursing students' attitudes, experiences, knowledge, and education concerning end-of-life care. Int J Palliat Nurs. 2014;:395-401.

8. Inci F, Oz F. Palliative care and death anxiety. Current approaches in psychiatry. 2012; 4:178-87.

9. Özer Z, Yıldırım D, Bölüktaş P. Attitudes of nursing students towards death. J Economic Social Res. 2015;2:1-13.

10. Xu F, Huang $K$, Wang $Y$, et al. Questionnaire study on the attitude towards death of the nursing interns in eight teaching hospitals in Jiangsu, China. BioMed Res Intern. 2019;1-8.

11. Üstükuş A. Investigation of the effects of nurses' death anxiety on their approach to deadly patient. Cukuova university Health Science Institute Master Thesis, Adana, 2019.

12. Youssef HA. Nursing students' perception of dying and their contextualizing end of life and palliative care in nursing curriculum at Taif University. Eur $\mathrm{J}$ Academic Essays. 2016;3:93-9.

13. Cokluk O, Yilmaz K, Oguz EA. Qualitative interview method: focus group Interview. J Theoretical Educat Science. 2011;4:95-107.

14. Kartal $H$, BalantekinY, Bilgin $A$, et al. Factors affecting bullying in home and school life: a mixed method research. Journal of Qualitative Research in Education 2019;7:50-85.

15. Isik E, Fadiloglu O, Demir YA. Study of the reliability and validity of the Turkish version of death attitude profile in the nurse population. Turk Journal of Res Development Nurs. 2009:11:28-43.

16. Koku F, Ates M. Nurses' experiences and attitudes towards death in ımproving the quality of terminall ıll patient care. $\mathrm{J}$ Health Nurs Management. 2016:2,3:99-104.

17. Yilmaz E, Vermisli S. Attitudes of intensive care unit nurses toward death and provision of care to terminally ill patients. Celal Bayar University J Institute Health Sciences. 2015;2:41-6.

18. Erdogan S, Nahcivan N, Esin N. Research in Nursing (First Edition). Nobel Tıp Kitabevleri Tic.Ltd.Şti.,150-155, İstanbul, 2014.

19. Gürdogan PE, Kınıcı E, Aksoy B. The relationship between death anxiety and attitudes toward the care of dying patient in nursing students. Psychol Health Med. 2019;24:843-52.

20. Ferrell B, Malloy P, Mazanec P, et al. CARES: AACN's new competencies and recommendations for educating undergraduate nursing students to improve palliative care. 
J Professional Nurs. 2016;32:327-33

21. Selçuk TK K, Avcı D. The attitude of health high school students towards death and related factors. Literatür Sempozyum 2015;8:26-32.

22. Bilge A, Embel N, Kaya FG. Attitudes of health professional students to death and the relationship between death anxiety and the variables affecting them. J Psy Nurs. 2013;4:119-24.

23. Kumar S, Chris E, Pais M, et al. Nursing students' perceived attitudes towards death: a cross-sectional survey. Indian J Forensic Med Pathol. 2013;7:5-15.

24. Yılmaz E, Vermişli S. Intensive care nurses' attitudes toward death and caring for dying patients. CBU-SBED. 2015;2:416.
25. Taşdemir G, Gök F. Determining death anxiety among health school students. International J Human Science [Online]. 2012;9:303-17.

26. Ay F, Gencturk N. Midwifery student's opinions related to death, terminal period and palliative care: focus group study. Florence Nightingale J Nurs. 2013; 21:164-71.

27. Cavdar I. Care of the cancer patient in the terminal period. Turk J Oncol. 2011;26:142-7.

28. Gurkan A, Gumus AB, Dodak $H$. The opinions of nursing students about Issues of terminal stage patients: the Investigation in the context of nursing interventions, patient rights and ethical Issue. M. Ü. J Nurs Science Art. 2011;4:212. 